\title{
Development of a Training Manual for Reducing Use of Pesticides by Para Rubber Farmers at Bueng Khan Province, Thailand
}

\author{
Tivapron Kombusadee ${ }^{1} \&$ Jurairat Kurukodt $^{1}$ \\ ${ }^{1}$ Department of Environmental Education, Faculty of Environment and Resource Studies, Mahasarakham \\ University, Maha Sarakham 44150, Thailand \\ Correspondence: Tivapron Kombusadee, Department of Environmental Education, Faculty of Environment and \\ Resource Studies, Mahasarakham University, Maha Sarakham 44150, Thailand. E-mail: tivaponk@gmail.com
}

\author{
Received: February 11, 2021 Accepted: March 21, 2021 Online Published: April 12, 2021 \\ doi:10.5539/jel.v10n3p48 URL: https://doi.org/10.5539/jel.v10n3p48
}

\begin{abstract}
It is widely known that systematically developed training manuals can be used to improve knowledge and practical skills and promote positive attitude of trainees. This research thus aimed to develop a training manual to help reduce the use of pesticides by para rubber farmers in Nonkheng Sub-district, So Phisai District, Bueng Khan Province, Thailand. The research was divided in to 3 stages. The first stage investigated the scenarios in which pesticides were used of the para rubber famers while the second stage dealt with the development of a training manual for promoting the reduction of the use of pesticides and hazardous chemicals by the farmers. The final stage was the evaluation for the efficiency of the developed training manual by applying it with 48 volunteered para rubber famers for 2 days. The findings revealed that the training manual had an efficiency of index at $80.38 / 80.89$. After training with the manual, the farmers' levels of knowledge increased tal $67.40 \%$, while the overall post-test scores on knowledge, attitude, and practice skills in reducing the use of pesticides were found to be significantly higher $(p<0.05)$ than those of the pre-test. It can be concluded that the developed training manual can be effectively used to improve the knowledge, attitude, and practical skills of the trainees.
\end{abstract}

Keywords: training manual for pesticide reduction, para rubber famers, knowledge, attitude, practical skills

\section{Introduction}

\subsection{Introduce the Problem}

Pesticides' poisoning is one of the major problems and global concern. In recent years, there have been pressing public health and food safety and environmental condition concerns related to pesticide residues (Gesesew, Woldemichael, Massa, \& Mwanri, 2016; Bhusnure, Dongare, Gholve, \& Giram, 2018). Farmers are the largest groups of workforce in the world consisting of over 1.1 billion individuals (Ghafari, Cheragh, \& Irani, 2017). They are particularly at high risk of pesticide poisoning due to high risk from occupation exposure. Pesticides have critical effects on human health including: headache, nausea and vomiting, skin rashes, irritation and abdominal pain (Oztas, Kurt, Koc, Akbaba, \& Ilter, 2018; Rostami, Afshari, Moez, Assari, \& Soltanian, 2019). According to the National Statistic Office (2015), Thailand has more than 11.4 million farmers which approximately $38 \%$ of the total population and there are approximately 500 million square meters of land in Thailand and about $47 \%$ of it was used for agriculture. In addition, the Thai Government policy-driven rubber plantation has led widespread land conversion (Sakayarote \& Shrestha, 2016). Thai Farmers changed their production system, developed into monoculture, which had to rely on external factors to produce (Siriwatthanmichai \& Kurukodt, 2018). Pesticides have been heavily used in the rubber planting process, aiming to repel insects and other enemies of rubber plants are most frequently used in rubber farming $(89.49 \%)$, followed by pesticides and herbicides at $80 \%$ and $76.61 \%$, respectively. In the past five years, the use of these chemicals has soared by $79.32 \%$ (Rangkawat \& Sittisak, 2015). The practice of using pesticides for agricultural purposes had caused illnesses among famers to have the prevalence of allergies, nasal congestion, wheezing and acute symptoms (Phajan, Nilvarangkul, \& Settheetham, 2014; Kongtip et al., 2018). Based on an investigation of the farmers' blood specimens for three years from 2012 to 2014, it was shown that the proportion of the people, who had undergone blood testing and the people diagnosed with blood contamination, were as follows: 244,822 : 75,$749 ; 314,805: 96,227$; and $317,051: 107,820$, which are equivalent to $30.94 \%, 30.57 \%$ and $34 \%$, respectively. The number of people who are being affected by dangerous agricultural chemicals is apparently soaring annually 
(Department for Disease Control Ministry of Public Health, 2015).

\subsection{Explore Importance of the Problem}

Growing rubber trees strips away soil health and fertility because the nutrients in the soils are used to produce the plants' sap. Soils from the rubber plots were found to be contaminated with agricultural chemicals (Jansamood, 2013). Residues from rubber plots are washed away and dissolved into water sources (Department for Pollution Control, Agricultural Sewage Section, 2013). In order to solve the problems related to using pesticides in rubber plots, the farmers should be trained on how to appropriately use the chemicals on their rubber plantations (Waroonrat, 2014). It is equally important to create awareness of the dangers of agricultural chemicals. Moreover, those, who plant rubber trees, should take part in monitoring the use of dangerous chemicals on their lands (Wongphon \& Inmoong, 2012). Data from Nonkheng Health Promoting Hospital show that 667 families grow rubber trees in the vicinity of the hospital. These farmers have consistently used chemicals pesticides in their rubber plots and these farmers are likely to become vulnerable to many health problems. Based on a three-year reference (2014-2016), chronic illness that causes death from major diseases including Septicemia, heart failure, acute myocardial infarction and Breast cancer is reported to be related to pesticide poisoning. In addition, Cholinesterase enzyme analyses with blood contamination, were as follows: $1,246-475,1,295-511$, and 1,465-624. These figures are equivalent to $38.14 \%, 39.45 \%$ and $42.60 \%$, respectively. This means that farmers are at risk of pesticide poisoning (Sophisai Public Health Office, 2016).

\subsection{Describe Relevant Scholarship}

From the problems and concerns mentioned above, the researcher is interested and attempting to help solve the problems related to the use of pesticides among the farmers. According to studies, factors contributing to the morbidity and impact on the environment of pesticide exposure included lack of training and limited knowledge and awareness of pesticide's danger, misleading attitude towards pesticides, inappropriate practical skills in using pesticides, non-use or inappropriate use of personal protective equipment (Christos, Damala, Spyridon, \& Koutroubas, 2015; Elikana, Lekei, Aiwerasia, Ngowi, \& Leslie, 2014). In order to solve the problems related to using pesticides, the farmers should be trained on how to appropriately use the pesticides (Sapbamerer, 2018; Kaewbooonchoo, Kongtip, \& Woskie, 2018). The use of appropriately designed training manual can help develop the knowledge, positive and right attitude toward the use of pesticides and more practical skills (Siriwatthanamichai \& Kurukod, 2018; Wanlu, Singseewo, \& Suksringarm, 2015). Therefore, the researcher has developed a training manual for the reduction of the use of pesticides for para rubber farmers in Nonkheng Sub-district, So Phisai District, Bueng Khan Province, Thailand. The manual developed for this research should be use to train the rubber farmers. It is expected that the "trained farmers" would be able to obtain knowledge attitude and practice skills on how to appropriately use pesticides on their rubber farms, which should help to reduce the dangers of chemical usage on rubber plantations, while making rubber farming more environmentally friendly.

\section{Objectives}

1) To investigate the current situation in the use of pesticides by the para rubber famers living in Nonkheng Sub-district, So Phisai District, Bueng Khan Province, Thailand.

2) To developed a training manual for the reduction of the use of pesticides by the farmer to have an efficiency level of $80 / 80$.

3) To investigate and compare the pre-test and the post-test scores of the knowledge, attitudes, and practical skills relating to the use of pesticides and dangerous chemicals among the farmers who attended the training.

\section{Materials and Methods}

\subsection{Study Design, Population and Samples}

This research implemented a mixed methods research design and was divided into 3 stages as follows:

Stage 1 was to investigate the scenarios in which pesticides were used by the para rubber famers. Data were obtained from 250 participants recruited by using the Taro Yamane (Yamane, 1967) formula and the stratified random sampling technique. A questionnaire on the use of pesticides was distributed to the 250 -sample group to collect the scenario of pesticide use by the participants. The questionnaire was divided into two main parts: personal information and types and quantity of each pesticide used. The personal information part deals with personal data of the participants including age, gender, marital status, education, and experience in para rubber farming. The types and quantity of use part is to investigate the types of pesticides they often use and how frequently they use them: high (more than five times per year), moderate (three to four times a year) low (one to 
two times per year), and None (no use of pesticides). The sample group was also blood-tested to examine pesticide residues in their blood. The data gained from the questionnaire and blood test result were used as fundamental data for designing the training manual forv reducing the use of the pesticides found, in Stage 2.

Stage 2 was the development of a training manual. The data on the types and quantity of pesticides used and the blood test results were used as fundamental information for selecting the types of pesticides to be included in the training manual. The knowledge regarding an appropriate and correct use of each pesticide was taken from the information given to the public by Department for Disease Control, Ministry of Public Health (2015). The developed manual was validated by three experts: one was a public health official and the others were environmental officials. The developed training manual consists of four modules: Module 1: Knowledge on environmental and health impact of select chemical pesticides, Module 2: Knowledge on appropriate and correct amount of selected pesticides to be safely used, Module 3: Introduction to personal protective equipment and Module 4: Preventive measures for chemical and pesticide poisoning. 48 volunteers were given the training using the developed manual for two days. Before the training, the pre-test on knowledge and questionnaire on attitude were administered to the 48 participants.

Stage 3 was the evaluation of the efficiency of the developed training manual. After the second day of the training, the post-test on knowledge and questionnaire on attitude were administered to the 48 volunteers to investigate the improvement of their knowledge and attitude towards the use of pesticides. The practical skill questionnaire in the use of pesticides was evaluated one month after the training. All scores receiving from the knowledge test, attitude questionnaire and practice skill questionnaire were calculated for means and standard deviation and the researcher set the mean levels for interpretation as follows: Knowledge: $32.10-40$ is the highest, $24.10-32$ is high, 16.10-24 is moderate, $8.10-16$ is low, $0-8$ is the least, Attitude: $4.51-5.00$ is strongly agree, $3.51-4.50$ is agree, $2.51-3.50$ is uncertain, $1.51-2.50$ is disagree, $1.00-1.50$ is strongly disagree, and Practice skills: $4.51-5.00$ is all the time, $3.51-4.50$ is often, $2.51-3.50$ is sometime, $1.51-2.50$ is infrequent, and 1.00-1.50 is never.

\subsection{Certificate of Approval}

Approval number: 069/2018

\section{Research Instruments}

1) Questionnaires were used to investigate the situation related the use of pesticide in para plantations at Nonkheng Sub-district, So Phisai District, Bueng Khan Province, Thailand; and the examination of the chemical residues in farmers was performed by using Reactive Paper for blood test, respectively. For the residue test in humans, the farmers' blood specimens were tested to find evidence of the Cholinesterase enzyme.

2) A knowledge, attitude and practical skill tests to determine the villagers' degree of understanding about the measure for reducing the use of pesticides in Nonkheng Sub-district, So Phisai District, Bueng Khan Province.

\section{Collection of Data}

The data collection was carried out by using questionnaires and determining the participants levels of Knowledge, Attitude and Practical skills related to reducing the use of pesticides prior to and after the training.

\section{The Statistics Used}

Descriptive statistics including percentiles, mean, and standard deviation, as well inferential statistical test of pair t-test to the 0.05 significant level were used to present general findings relating to the participants' level of Knowledge, Attitude and Practice skills before and after the training using the manual. The instrument's efficiency was evaluated by testing the process efficiency (E1) and the result efficiency (E2).

\section{Results}

The research findings are presented 3 stages as fllows:

Stage 1: The survey on the use of pesticides of the Para Rubber Farmers and the test of the chemical residues in the para rubber famers in Nonkheng Sub-district, So Phisai District, Buengkhan Province was administered to the 250 participants. The results showed that the mostly used pesticide was Lanate $(46 \%)$, followed by Carbofuran (31.9\%), Dicrotophos (28.4\%), and Methamidophos (8.40\%) respectively. For blood test result, it was found that of the 250 participants, more than half of the participants $(57.60 \%)$ were at risk or unsafe level as shown in Tables 1 and 2.

Stage 2: The result of the evaluation of the efficiency and effectiveness of the developed a manual with the level of $80 / 80$ showed that the developed training manuscript had been rated at an efficiency of $80.38 / 80.89$, which was higher than the anticipated rate as shown in Table 3. This effectiveness score of 80.38/80.89 shows that the 
manual developed for this research had met the E.I. standard of $80 / 80$, ensuring that the manual is an effective medium used for Stage 3. The manual is expected to be effective for training the para rubber farmers to obtain knowledge attitude and practice skills on how to appropriately use pesticides on their rubber farms, which should help to reduce the dangers of chemical usage on rubber plantations.

Stage 3. The result of the implementation of the training manual with 48 volunteers showed that the para rubber famers had higher knowledge, attitude, and practice skills on the application of pesticides after attending the training program for reducing the use of pesticides as shown in Table 4

Table 1. Levels the used of pesticides of the para rubber Farmers in Nonkheng Sub-district, So Phisai District of Bueng Khan Province $(\mathrm{n}=250)$

\begin{tabular}{|c|c|c|c|c|c|c|c|c|c|c|c|}
\hline \multirow{2}{*}{ Main use } & \multirow{2}{*}{ Common name } & \multirow{2}{*}{ Chemical group } & \multirow{2}{*}{$\begin{array}{l}\text { WHO } \\
\text { class }\end{array}$} & \multicolumn{2}{|l|}{ High } & \multicolumn{2}{|l|}{ Moderate } & \multicolumn{2}{|l|}{ Least } & \multicolumn{2}{|l|}{ No use } \\
\hline & & & & $\mathrm{N}$ (person) & $\%$ & $\mathrm{~N}$ (person) & $\%$ & $\mathrm{~N}$ (person) & $\%$ & $\mathrm{~N}$ (person) & $\%$ \\
\hline \multicolumn{12}{|l|}{ Pesticides } \\
\hline & Lanate & Carbamate & II & 115 & 46 & 44 & 17.6 & 53 & 21.2 & 38 & 15.2 \\
\hline & Carbofuran & Carbamate & II & 81 & 31.9 & 11 & 4.4 & 57 & 22.8 & 84 & 33.6 \\
\hline & Dicrotophos & Organophosphate & II & 71 & 28.4 & 12 & 4.8 & 62 & 24.8 & 97 & 38.8 \\
\hline & Methamidophos & Organophosphate & II & 21 & 8.4 & 26 & 10.4 & 61 & 24.4 & 141 & 56.4 \\
\hline
\end{tabular}

According to Table 1, the percentile score the para rubber Farmers used of pesticides was $46 \%$, which was at high level.

Table 2. The levels of Cholinesterase enzyme contaminating the Farmers' Blood Specimens $(n=250)$

\begin{tabular}{|c|c|c|c|c|c|c|c|}
\hline Normal & & Safe & & Risk & & unsafe & \\
\hline $\mathrm{N}$ (person) & $\%$ & $\mathrm{~N}$ (person) & $\%$ & $\mathrm{~N}$ (person) & $\%$ & $\mathrm{~N}$ (person) & $\%$ \\
\hline 49 & 19.6 & 57 & 22.8 & 96 & 38.4 & 48 & 19.2 \\
\hline
\end{tabular}

According to Table 2, the percentile score of cholinesterase enzyme contaminating was $38.4 \%$, which was at risk level.

Table 3. Effectiveness Index (E.I) of the manual for prevention of pesticides use in rubber plots

\begin{tabular}{lllll}
\hline Manual efficiency & Full score & $\overline{\mathrm{x}}$ & S.D. & Percentile \\
\hline Process efficiency $\left(\mathrm{E}_{1}\right)$ & 38 & 32.14 & 0.7 & 80.38 \\
Effectiveness of results $\left(\mathrm{E}_{2}\right)$ & 40 & 32.35 & 2.51 & 80.89 \\
The efficieness of the manual $(\mathrm{E} 1 / \mathrm{E} 2)=80.38 / 80.89$ & & & \\
\hline
\end{tabular}

According to Table 3, the effectiveness index of the manual was $80.38 / 80.89$, had met the effectiveness index standard of $80 / 80$

Table 4. Comparison of pre-test and post-test scores on knowledge, attitude, and practice skills on the prevention of pesticides use in rubber plantations

\begin{tabular}{|c|c|c|c|c|c|c|c|c|c|}
\hline \multirow[t]{2}{*}{ pesticides prevention } & \multicolumn{3}{|c|}{ Before training } & \multicolumn{3}{|c|}{ After training } & \multirow[t]{2}{*}{$\mathrm{t}$} & \multirow[t]{2}{*}{ df } & \multirow[t]{2}{*}{$\mathrm{P}$} \\
\hline & $\overline{\mathrm{x}}$ & S.D. & Level & $\overline{\mathrm{x}}$ & S.D. & Level & & & \\
\hline Knowledge $(\mathrm{N}=40)$ & 15.18 & 6.05 & Least & 32.35 & 2.51 & Highest & 18.09 & 47 & $.000^{*}$ \\
\hline Attitude $(\mathrm{N}=33)$ & 3.06 & 0.18 & uncertain & 4.05 & 0.30 & Agree & 18.46 & 47 & $.000^{*}$ \\
\hline Practice skills $(\mathrm{N}=31)$ & 3.19 & 0.23 & Sometimes & 4.30 & 0.18 & Often & 18.09 & 47 & $.000^{*}$ \\
\hline
\end{tabular}

Note. $* * \mathrm{p}<0.05$.

According to Table 4, the mean score of pretest before training knowledge was 15.18 , attitude was 3.06 and practice skills was 3.19 , while the posttest after training knowledge was 32.35 , attitude was 4.05 and practice skills was 4.30 , showed the significantly higher of the posttest after training than that of the pretest before training at the 0.05 . 


\section{Discussion}

The first finding of the study revealed that the farmers working in Nonkheng Sub-district, So Phisai District, Bueng Khan Province, Thailand have used chemicals in all steps of rubber growing: planting the rubber saplings, weeding and repelling pesticides, activating the rubber sap, and herbicides. Pesticides was found to be the most frequently used repellant because of its quick response to removing weeds and its ability to compensate for the lack of labor in rubber families, which had been reported to average between one and two workers per home. Similar results were found pesticides being used most often in rubber plantations into rubber production in Bueng Khonlong District, Bueng Khan Province, Thailand (Borisut, Khibtong, \& Yooprasert, 2014). A similar study showed that pesticides were used most often in rubber plantations (46.34\%, Kaewka, 2014). The cholinesterase enzyme test conducted on the farmers' blood specimens indicated that 57.60 percent of the farmers had experienced being at-risk for health problems due to their direct exposure to chemicals during the processes using pesticides and herbicides. Similar studies examining the effects of using pesticides substances by rice farmers and the effects on the environment found that 58 percent of the farmers had a residue contamination risk level (Paipard, Supannatas, \& Suttiprapa, 2014) and it was also found that $53.30 \%$ of the Para rubber farmers had level at risk of studies the health impact (Jansamood, 2013).

The second finding with regard to the effectiveness of the manual in promoting the reduction of chemical use in rubber plantations showed that the overall score of the trainees (E1) was 80.38. The average score, which had been rated after the completion of the training, was 80.89. This effectiveness score of $80.38 / 80.89$ showed that the manual developed for this research had met the E.I. standard of $80 / 80$, ensuring that the manual is an effective medium for training on pesticides use reduction. The manual matching the E.I. can be explained by the systematic creative processes as follows: 1) the content development process had been tailored carefully by reviewing related documents; 2) the manual's contents and validity had been revised and shaped following the recommendations of the experts was revised by and effectiveness of the training manual and determination of the strument qualities. This concept aligns with results from a study by on the development of manual for undergraduate learners on the topic of Biological and Practical Bio-environmental Integrated Learning The effectiveness Index (E.I.) of the manual developed in Boonnan study was observed to be at $80.55 / 81.85$, which is higher than the reference rate of $80 / 80$. The effectiveness of the outcome was rated at 0.751 , which predicted that the students' knowledge would increase by 75.51 percent after the application of the manual (Bunnaen, Kurukotd, \& Appamaraka, 2015). Similar results were observed in a study by Kulsuwan developed a manual for integrative instruction on the Economy and the Environment for Bachelor Degree learners. The effectiveness Index (E.I.) of the manual developed in Patticha study was observed at 89.49/82.00, which is higher than the reference rate of $80 / 80$. Moreover, the effectiveness of the outcome was rated at 0.534 , which predicted that the students' knowledge would increase by 54.40 percent after the application of the manual (Kulsuwan \& Kurukotd, 2015).

The last stage compared the average scores on knowledge, attitude, and practice skills of the para rubber farmers from Nonkheng Sub-district, So Phisai District, Bueng Khan Province before and after training. The knowledge, attitude, and practical skills in the use of pesticides in rubber plantations before training were low. However, after the training, the average scores became higher at the 0.05 level. This is because the training manual contains useful knowledge and give appropriate instructions on the use of pesticides for farming. It also educates the farmers to use the right protective gears when using pesticides in the farms. Similar studies by Negatu reported farmers lack of training and knowledge regarding the safe use of pesticides (Negatu, Kromhou, Mekonnen, \& Vermeulen, 2015). However, the post-test scores in these three areas were significantly higher than the pre-test scores $(\mathrm{p}<0.05)$. The increase in scores in the post-test was brought about by the many activities in the training that participants had engaged in. The training was also carried out systematically from initial activities to discussions, analyses, and evaluations. Moreover, the training deployed a lot of mediums for learning, which included the training manual, training used of personal protective equipment (PPE) practice skill and Power Point presentations, among others. The act of increasing the informers' comprehension was also articulated in a study by Kulsuwan developed a manual for the integrative instruction of the economy and the environment for bachelor's degree students. In Patticha's study, it was shown that the students' post-test scores were significantly higher than their pre-test scores $(\mathrm{p}<0.05)$ (Kulsuwan \& Kurukotd, 2015). Similar findings were observed by On-moy who conducted research on the application of a collaborative approach in prventing chemical use among onion farmers. It was shown in On-moy study that post-test scores on knowledge, attitude, and chemical prevention practices had been significantly higher $(\mathrm{p}<0.05)$ than the figures recorded in the pre-test (Onmoy \& Anungudornpukdee, 2016). 


\section{References}

Bhusnure, O. G., Dongare, R. B., Gholve, S. B., \& Giram, P. S. (2017). Chemical hazardous and safety management in pharmaceutical industry. Journal of Phamacy Research, 12(3), 357-369. Retrieved from https://www.researchgate.net/publication/324504675

Borisut, S., Khibtong, J., \& Yooprasert, B. (2014). Para rubber production by famers in Bueng Khong Long District of Bueng Kan Province (p. 9). The 4 th STOU graduate research conference.

Bunnaen, W., Kurukotd, J., \& Appamaraka, S. (2015). The development of biology and biological laboratory hand book integard learning using for bachelor degree Student Faculty of Environment and Resource studies, Mahasarakham University. Journal of Education, 9(4), 176-190.

Christos, A., D., \& Spyridon, D. K. (2015). Farmers' Exposure to Pesticides: Toxicity Types and Ways of Prevention. Toxics, 4(1), 1-10. https://doi.org/10.3390/toxics4010001

Department for Disease Control, Disease Monitoring and Controlling Ministry of Public Health. (2015). Report on the impacts of agricultural chemical usage among farmers. Retrieved September 22, 2018, from http://envocc.ddc.moph.go.th/

Elikana, E. L., Aiwerasia, V. N., \& Leslie, L. (2014). Hospital-based surveillance for acute pesticide poisoning caused by neurotoxic and other pesticides in Tanzania. NeuroToxicology, 45, 318-326. https://doi.org/10.1016/j.neuro.2014.02.007

Food and Agriculture Organization of the United Nations. (1999). Storage and stock contral manual. Rome Italy.

Food and Agriculture Organization of the United Nations. (2001). FAO training manual for inventory taking of obsolete pesticides. FAO pesticides disposal series 10. Rome Italy.

Gesesew, H. A., Woldemichael, K., Massa, D., \& Mwanri, L. (2016). Farmers knowledge, attitudes, practices and health problems associated with pesticide use in Uural Irrgation Villages, Southwest Ethiopia. PLOS ONE. https://doi.org/10.1371/journal.pone.0162527

Ghafari, M., Cheragh, Z., \& Irani, A. D. (2017). Occupational risk factors among Iranian farmwokers: A review of the available evidence. Epidemiology and Health, 39, 19. https://doi.org/10.4178/epih.e2017027

Jansamood, C. (2013). Environmental impact and health impact from pesticide of para rubber farmers at Phon Sub-district, Kham Muang District, Kalasin Province. Research Journal of Applied Sciences, 8(5), 268-270. https://www.researchgate.net/publication/292451810

Kaewbooonchoo, O., Kongtip, P., \& Woskie, S. (2018). Ocuupational Health and Safety for Agricultural Workers in Thailand: Gaps and Recommendations, with a Focus on Pesticide Use. New Sulut. Retrieved from https://journals.sagepub.com/doi/10.1177/1048291115569028

Kaewka, T. (2014). The risks in pesticide usage among the farmers in Wang Thong Sub-district, Nawang District, Nongbua Lamphu Province. Journal of Community Health Development of Khon Kaen University, 2(4), 117-128.

Kongtip, P., Nankongnab, N., Mahaboonpeeti, R., Bootsikeaw, S., Batsungnoen, K., Hanchenlaksh, C., ... Woskie, S. (2018). Differences among Thai Agricultural Workers' Health, Working Conditions, and Pesticide Use by Farm Type. Ann Work Expo Health, 62(2), 167-181. https://doi.org/10.1093/annweh/wxx099

Kulsuwan, P., \& Kurukotd, J. (2015). The developing of hand book with integrated to learning and teaching environmental economics for undergradue to students Mahasarakham University. Journal of Education (Mahasarakham University), 9(4), 126-141.

National Statistical Office. (2015). The survey results of job characteristic in Thai people (online). Retrieved August 12, 2018, from http://service.nso.go.th/nso/nsopublish/themes/files/lfs58/reportFeb.pdf

Negatu, B., Kromhou, H., Mekonnen, Y., \& Vermeulen, R. (2015). Use of chemical pesticides in Ethiopia: A cross-sectional comparative study on knowledge, attitude and practice of famers and farm Workers in three farming systems. Ann. Occup Hyg., 60(5), 551-566. https://doi.org/10.1093/annhyg/mew004

Onmoy, P., \& Anungudornpukdee, P. (2016). Utilization of participation process to prevent health impact from pesticide use in shallot farming, Chaijumphon Sub-district Laplat District, Uttaradit Province. Journal of Health Scinece, 25(4), 596-603. 
Oztas, D., Kurt, B., Koc, A., Akbaba, M., \& Ilter, H. (2018). Knowledge level, attitude, and behaviors of Farmers in Cukurova Region regarding the use of pesticides. Biomed Research International, Artivle ID 6146509, 1-7. https://doi.org/10.1155/2018/6146509

Paipard, N., Supannatas, S., \& Suttiprapa, T. (2014). Effects of pesticide use on farmers health and the environment in Rong Kham District, Kalasin Province. Khon Kaen Agriculture, 42(3), 301-310.

Phajan, T., Nilvarangkul, K., \& Settheetham, D. (2014). Work-related musculoskeletal disorders among sugarcane farmers in North-Eastern Thailand. Asia Pac $J$ Public Health, 26, 320-327. https://doi.org/10.1177/1010539514528026

Rostami, F., Afshari, M., Moez, M. R., Assari, M., \& Soltanian, A. R. (2019). Knowledge, attitude, and praxtice of pesticides use among Agricultural Workers. Indian Journal of Occupation\& Environmental Medicine, 23(1), 42-47. https://doi.org/10.4103/ijoem.IJOEM_153_18

Rungkawat, N., \& Sittisak, P. (2015). Sustainable analysis of agricultural systems in Chiangmai Province: Rubber-base systems. Research report of Faculty of Agricultural Maejo University.

Sakayarote, K., \& Shrestha, R. P. (2016). Policy-driven rubber plantation and its driving facture: A case of smallholders in northeast Thailand. International Jounal of Sustainable Development \& World Ecology, 24, 15-26. https://doi.org/10.1080/13504509.2016.1143410

Sapbamerer, R. (2018). Pesticide use, poisoning, and knowledge and unsafe occupation practices in Thailand, New Solution a Journal of Environmental and Occupational Health Policy, 28(2), 283-302. https://doi.org/10.1177/1048291118759311

Siriwatthanamichai, N., \& Kurukod, J. (2018). The development of organic farming promoting manual for agriculturists of Ban Nongtokpan Tambon Nongtokpan, Amphoe Yang Talat, Kalasin province. International Journal of Agricultural Technology, 14(7), 1921-1930. https://www.researchgate.net/publication/332250662

Sophsai Phisai Public Health Office. (2016). Health report of the residence under the responsibility of Nonkheng Health Promoting Hospital.

Wanlu. S., Singseewo, A., \& Suksringarm, P. (2015). The development of knowledge and awareness of environmental laws and participation in environmental conservation of probationers. Academic Journal of Education Research and Reviews, 10(12), 1646-1650. https://doi.org/10.5897/ERR2015.2304

Wiroonratch, B. (2014). Potential in rubber planting in Northeastern Part. Journal of Management Science, 31(2), $37-63$.

Wongphon, S., \& Inmoong, U. (2012). Health risk assessment from rubber farming activities in Nongsang District, Udonthani Province. KKU Journal for Public Health Research, 5(1), 13-20.

Yamane, T. (1967). Statistics, An Introductory Analysis (2nd ed.). New York: Harper and Row.

\section{Copyrights}

Copyright for this article is retained by the author, with first publication rights granted to the journal.

This is an open-access article distributed under the terms and conditions of the Creative Commons Attribution license (http://creativecommons.org/licenses/by/4.0/). 